\title{
Evidence of Iron Mineralization Channels in the Messondo Area (Centre-Cameroon) Using Geoelectrical (DC \& IP) Methods: A Case Study
}

\author{
Ngoumou Paul Claude ${ }^{1}$, Ndougsa-Mbarga Théophile ${ }^{2 *}$, Assembe Stéphane Patrick¹, \\ Kofane Timoleon Crepin 1 \\ ${ }^{1}$ Department of Physics, Faculty of Science, University of Yaoundé I, Yaoundé, Cameroon \\ 'Department of Physics Advanced Teachers' Training College, University of Yaoundé I, Yaoundé, Cameroon \\ Email: ${ }^{*}$ theopndougsa@gmail.com
}

Received 1 April 2013; revised 2 May 2013; accepted 4 June 2013

Copyright (C) 2014 by authors and Scientific Research Publishing Inc.

This work is licensed under the Creative Commons Attribution International License (CC BY).

http://creativecommons.org/licenses/by/4.0/

c) (i) Open Access

\begin{abstract}
A geophysical survey was conducted in the Kelle-Bidjocka village, Messondo subdivision, in the Centre Region, Cameroon. The data acquisition was made by combining Schlumberger profiling and electrical soundings along six (06) profiles of $1500 \mathrm{~m}$ in length for a total of 64 geoelectrical stations' survey conducted through a variable mesh $100 \mathrm{~m} \times 200 \mathrm{~m}$, or $100 \mathrm{~m} \times 300 \mathrm{~m}$. The equipment used is the DC resistivimeter Syscal Junior 48 (Iris Instrument). Processing and modelling of field data are made by using the Res2Dinv, Qwseln and Surfer software. The investigation methods used are electrical resistivity (DC) and induced polarization (IP) methods. The analyses and interpretations have helped to highlight areas of weakness or conductive discontinuities (fractures, faults, shear zones, etc.) in Precambrian gneiss formations, sometimes undergoing weathering processes. They identify the weathering or mineralogical accumulation horizons, the most promising is a mineralization channel identified in the NE-SW direction. The highlighted mineralization is characterized by strong gradients of chargeability or polarization. Samples and other geological evidences observed in the area are used to associate the most polarizable structures with ferriferous formations. Weakly polarizable and particularly conductive backgrounds identified by the inverse pseudo-sections are thought to be sulphate minerals or groundwater targets for future hydrogeological studies.
\end{abstract}

\section{Keywords}

Direct Current; IP Method; Geoelectrical Surveys; Resistivity; Chargeability; Shear Zones;

${ }^{*}$ Corresponding author. 


\section{Iron Mineralization}

\section{Introduction}

The determination of hydro geological and mineral potential of a given region requires the prior knowledge of some geological evidence likely to enable a further investigation. It is in this purpose that a geoelectrical investigation was conducted in the Kelle-Bidjocka village (Messondo, Centre Cameroon). The approach of this study consists in measuring apparent resistivity and apparent chargeability through geoelectrical investigation combining electrical profiling and electrical soundings through the Schlumberger array. The investigation methods used are electrical resistivity (DC) and induced polarization (IP). The data will be processed with Res2Dinv, Qwseln and Surfer software.

The results, namely pseudo-sections and maps (resistivity \& chargeability), will enable to identify the various anomalies. The analyses and interpretations of these geoelectrical results will permit first, to realize geological cross sections and to map tectonic unevenness of the area under study, and secondly, to characterize the associated mineralogical nature.

\section{Geological and Tectonic Setting}

Recent studies [1]-[6] show that Central Africa in general and Cameroon in particular is essentially composed of a Precambrian basement consisting of magmatic and metamorphic rocks. These rocks belong to different periods of the Precambrian and outcrop in places. These are mainly granites and migmatites rejuvenated during the Panafrican episode.

Geological mapping shows that cities located between the coastal and the centre regions of Cameroon (Eséka, Messondo, Edea), are located in the transition zone between the Panafrican and the Congo Craton. This shear zone overlay a Precambrian basement (Figure 1), evidenced by the presence of major faults that are the Sanaga and the Kribi faults [7]-[10].

The study area (Kelle-Bidjocka) belongs to the Messondo subdivision, Nyong and Kelle division in the Centre Region (Figure 1). It is located between latitudes N 402,000 m and N 404,000 m, and stretches from longitude E $601,000 \mathrm{~m}$ to E 655,000 m, coordinates in WGS84 UTM33. Kelle-Bidjocka belongs to the peneplain bording, to the East, the cameroonian coastal plain, with elevations ranged between 100 and 150 meters. It presents symetrical ridges sometimes elongated over hundreds meters between which flood valleys are intercalated. However, the southern part is marked by dissimetrical down-cuttings caused by rocky slabs and scarps whose apex are generally plane, and on which one observes outcrops. The climate is of equatorial type with a very abundant rainfall.

The drainage is very dense. The drainage pattern is subparallel and locally dendritic. The main stream is the Dibanga, that flows ENE-WSW, with its several meanders flowing N-S. It is a West side tributary of the Kelle that flows N-S to the Nyong River. The drainage system is a hierarchical network with less incised meanders flowing on the rocky substratum and seem to follow tectonic lineaments.

\section{1) The BIFs and Itabirites}

The BIF and itabirites outcrop mainly centimeter block on the slopes and hilltops. These are very dense rocks, with a metallic luster and a strong magnetization. Itabirites (Figure 2) differ from BIF by their massive structure.

The BIF have a foliation marked by alternating (thicker, sometimes centimeter, consisting essentially of iron) light bands (thin, predominantly quartz-feldspar) and dark bands.

\section{2) The Gneisses}

Two types of gneisses are found in the area. The first type is encountered in the eastern part of the study area. They are fine grained and mesocratic, with feldspatitic dark layers. Their brown-reddish weathering suggests they may contain iron oxides in them. The samples, rich in potash feldspars, present few ferromagnesians minerals and content some iron oxide patches. These gneisses may constitute the origin of the light ferralitic soil of the region.

The second type of gneisses is encountered around granitic bodies in the West side of the study area. They are 


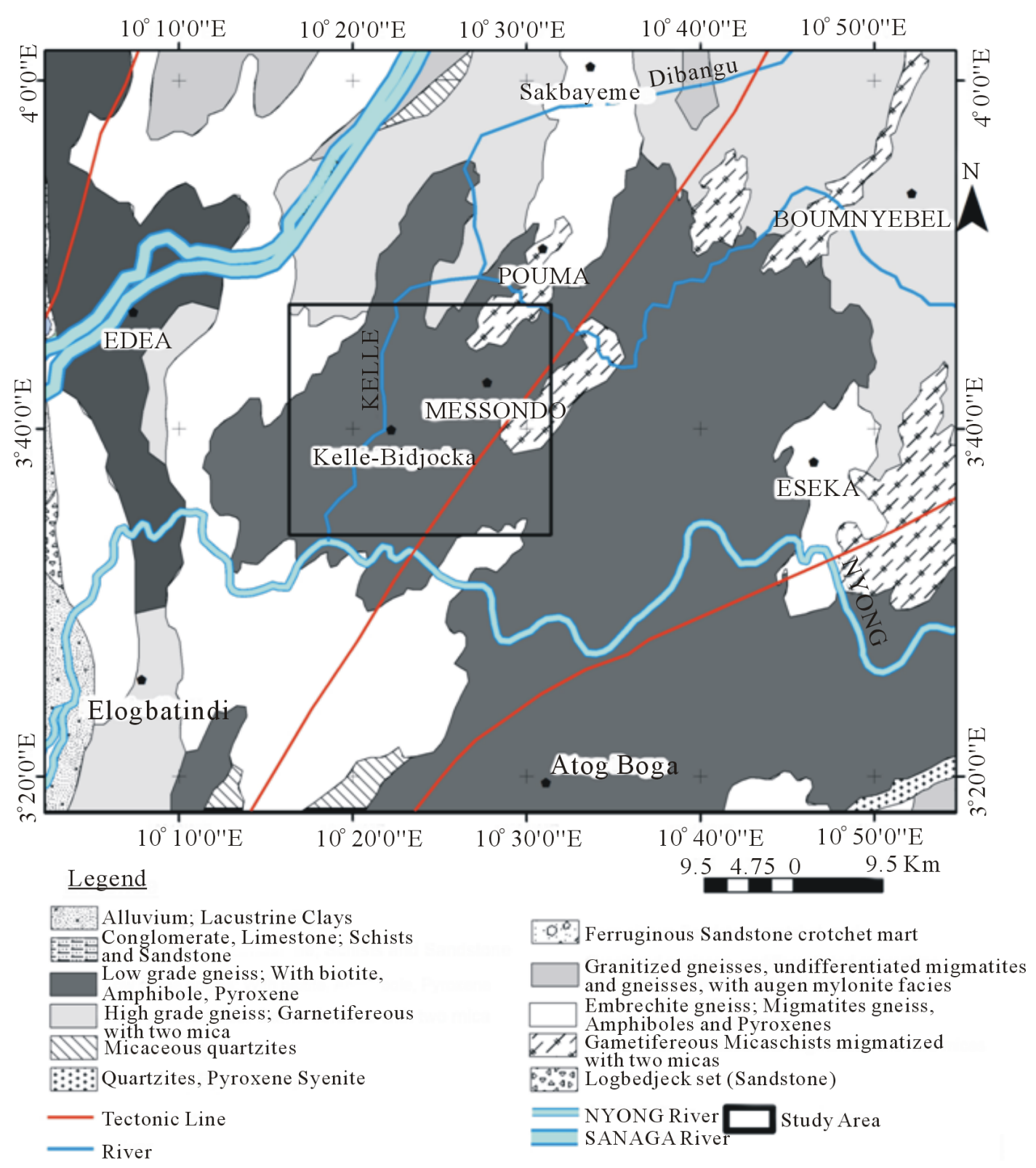

Figure 1. Geological map of the study area.

low grade feldspar gneisses without visible iron oxide patches. Meanwhile, their weathering is brown reddish and thus suggests that they may contain iron; their bedding relates them to paragneisses.

\section{3) Amphibolites}

They are melanocratic and fine grained with white patches on their oxydised area. They are low magnetic, but they are found were do iron mineralizations occur, notably along L2/L3 traverses.

Oxydised blocks outcrop in some parts and along rivers' banks. These blocks are rounded and porphyritic, with visible yellow patches. The Figure 2 thereafter shows summarily, the mapping of field observation of iron items.

\section{4) Granitoïds}

They are the oldest units in the area. These are crystalline rocks with a massive and average coarse texture. The mineralogical composition is quartz-biotite-feldspars with pinky potash feldspars accessories.

Fine grained granites looking like syenitic granites are also encountered. These granitoids have at all a faint schistosity. 

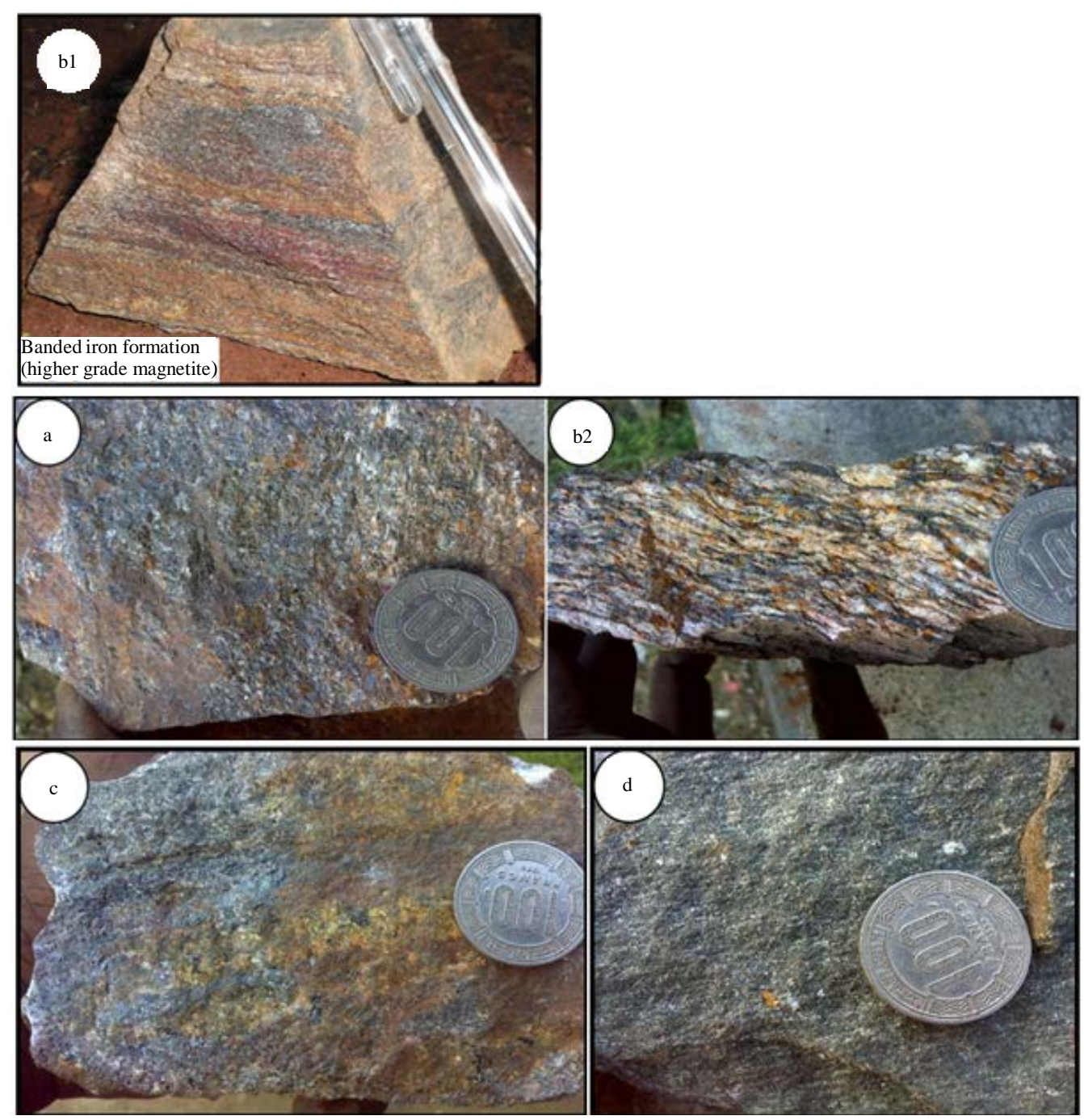

Figure 2. (a) Sample of itabirite; (b1, b2) Banded Iron Formation (BIF); (c) Sample of iron-bearing gneiss; (d) Sample of amphibolites.

\section{5) The dolerites}

The dolerites that outcrop in the area are often weathered by rain. The rock is light-gray and has a massive structure made up of millimetre crystals of quartz, feldspar, amphibole and biotite.

The main structural elements found in the area are:

\section{1) The foliation}

Generally, the foliation type is of compositional layering. It occurs in biotite gneiss and in BIFs.

In the biotite gneiss, the foliation is characterized by alternating mafic dark layers and quartz-feldspars' light levels. This foliation has two directions:

a) E-W (N75E-N97E) with low to moderate dips $\left(20^{\circ}-60^{\circ}\right)$, b) and a N-S direction with low-dipping $\left(12^{\circ}\right.$ $37^{\circ}$ ) to West (SW or NE).

In BIFs, the foliation is E-W (N40E-N65E) with mean NW dips $\left(38^{\circ}-47^{\circ}\right)$.

2) Fractures

Fractures occur in BIFs, gneisses and micaschists. These fractures are materialized by cracks, lineaments and faults. The fracturing generally presents a NE-SW (N32E-N45E) direction in gneisses, micaceous quartzites and dark micaschists. These fractures are post metamorphic in gneisses.

\section{3) Foldings}

The folds are seen much more in the iron formations made up of magnetite-quartz layers. These layers are 
strongly folded Figure 3(a). Predominantly, isopachyte folds witnessed by the folding of the foliation occur in BIFs. These folds have an axial plane direction N52 ${ }^{\circ}$ E Figure 3(b).

The soils in the area are of two types: hydromorphic soils in wetlands and ferruginous soils marked by the presence of hardpan on the tops and hillsides.

The observation of the mineralization in outcrop suggests that the area was marked by intense tectonics, and that this mineralization is controlled by a fault or mega fractures that are filled in with materials other than BIF and would meet in the swamps. Areas where do the iron formations outcrop are not continuous, and are in pick highs (altitude typically around $100 \mathrm{~m}$ ) and not present in the troughs forming swamps and beds of rivers. These wetlands are in filled fractures materials other than iron ore. The iron deposit, if any, would be in depth. Few mineralogical data are available on iron-bearing mineralization concerning the area under study. Solely, the testimony of the farmers states that it is while ploughing the ground that these small iron-bearing blocks are generally brought up to the surface. This suggests that iron could be concentrated in depth; hence this study combines the DC and IP method to determine the accumulation or iron-bearing mineralization targets in the area.

\section{Methods}

\subsection{Direct Current Method}

The electrical resistivity method establishes the relationship between the apparent resistivity $\left(\rho_{a}\right)$ of layers and depth [11]. Soundings are made on surface with a four electrodes device (Schlumberger array); the depth of investigation increases with the spacing of the injection electrodes [12].

The resistivity of materials is a good indicator and parameter for the nature and the weathering. Thus electrical prospecting methods have been used for a long time in geology and geotechnical engineering. These both qualitative and quantitative methods are based on the Ohm law [13] [14]: the injection of a very low frequency direct current in the ground and the measurement of the electrical potential (Figure 4) which enables to obtain the true resistivity of encountered formations.

In the study area, according to the geological setting, Schlumberger sounding and profiling methods have been used to determine both the thickness and the lateral extension, and the nature of formations encountered along a profile; and to highlight the geometry of geological bodies related to their contrasted electrical characteristics [15] [16].

Field electrical methods (DC) consist in a ground injection of an electrical current between two electrodes A and $\mathrm{B}$, and then, measuring the induced potential difference between two so-called potential electrodes $\mathrm{M}$ and $\mathrm{N}$ [17]. Since the current intensity is known and the potential measured, it is therefore possible to determine the ground apparent resistivity. This apparent resistivity depends of the current and potential electrodes array. The apparent resistivity $\rho_{a}$ (Rho) can be expressed function of the potential difference and the current intensity [2] [17] [18]:

$$
\rho_{a}=K \times V_{M N} / I_{A B}
$$

- $\boldsymbol{K}$ : geometric factor depending of the electrodes’ array.

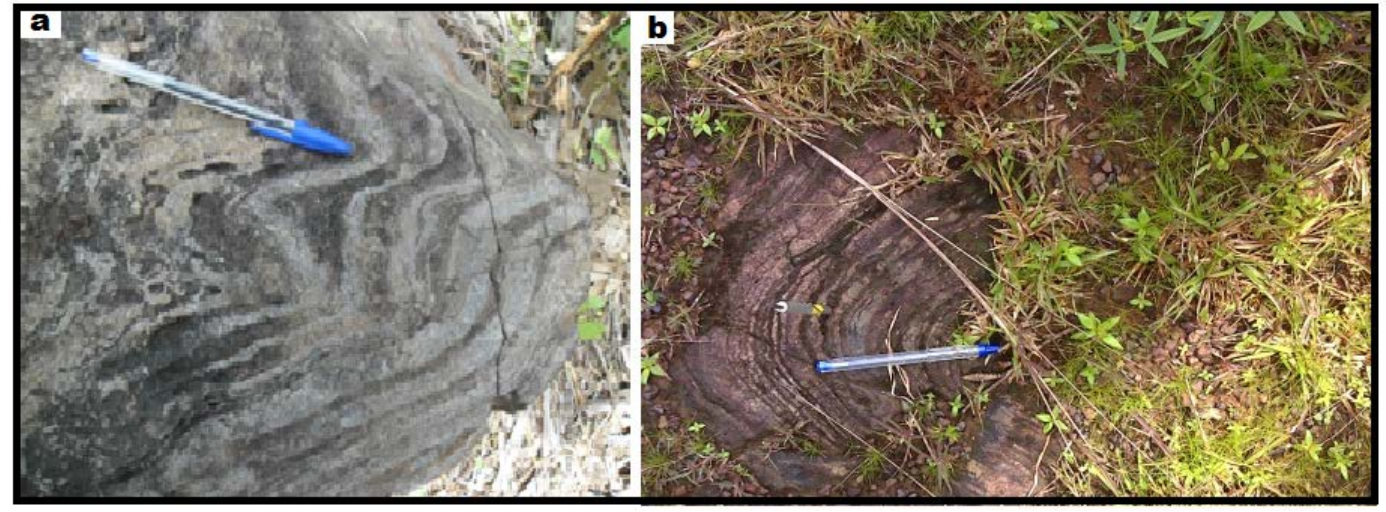

Figure 3. (a) Folds in the iron formation; (b) Isopach folds in the BIF. 


$$
K=2 \pi /\left(\frac{1}{A M}-\frac{1}{A N}-\frac{1}{B M}+\frac{1}{B N}\right), K \text { in } m
$$

$-V_{M N}$ : Potential difference between electrodes $\mathrm{M}$ and $\mathrm{N}$ in $m V$

- $I_{A B}$ : Electric current injected between electrodes A and B in $m A$

This resistivity value is used to characterize a formation. The resistivity depends mainly on the moisture condition and the proportion of clay in the soil volume concerned by the measure [2] [19] [20]. The clay and water are present in any voids. This enables to link the resistivity to characteristics such as fracturing and clay pollution of fractures and cracks, porosity, clay silt clogging [13] [19] [20].

\subsection{Induced Polarization (IP)}

The induced polarization (IP) method ameliorates electrical methods by measuring the apparent chargeability or chargeability of the earth material [13] [14] [21] [22].

The chargeability enables to assess the earth's capability to accumulate and return an electric current so do a capacitance when currents are injected then interrupted [12] [14] [21] [23]. The chargeability is measured by a ground injection of electric signal gaps (current (I)) using two injection (A and B) electrodes (dipole) while the potential difference is measured using two receiving electrodes (dipole), $M$ and $N$ (Figure 4). When IP effects occur, a voltage time decreasing curve $V_{s}(t)$ is observed at the receiving electrodes $\mathrm{M}$ and $\mathrm{N}$ during current stops between each gap [2] [14].

The chargeability $\boldsymbol{M}$ is defined as the ratio of the secondary voltage $\left(V_{s}\right)$ measured at a moment $t$ after the current stoppage over the primary voltage $\left(\boldsymbol{V}_{\boldsymbol{M N}}\right)$ measured before the current break [14] [21]:

$$
M=V_{s} / V_{M N}
$$

The secondary voltage can be measured at a single point after the stoppage of the current, but it is wise to consider a time lag for the measurement to be reliable [21]. The chargeability is then:

$$
M=\frac{1}{V_{M N}} \int_{t_{1}}^{t_{2}} V_{s}(t) \mathrm{d} t
$$

It appears that this value is independent of the current introduced in the earth. A time dependent transformation is often made in order to enable chargeability values to be comparable from one instrument to another [2]. So, the chargeability expression becomes:

$$
M=\frac{1}{\left(t_{2}-t_{1}\right) V_{M N}} \int_{t_{1}}^{t_{2}} V_{s}(t) \mathrm{d} t
$$

The chargeability is generally expressed in $\mathrm{mV} / \mathrm{V}$ or in $\mathrm{ms}$ The electric current flow within ground goes along with electrochemical processes whose intensity and characteristics are function of physical and chemical properties of the earth [22] [24]. This current flow can follow two patterns:

1) By electrical conductibility for which free electrons' motion occurs in metallic particles (pyrite, chalcopy-

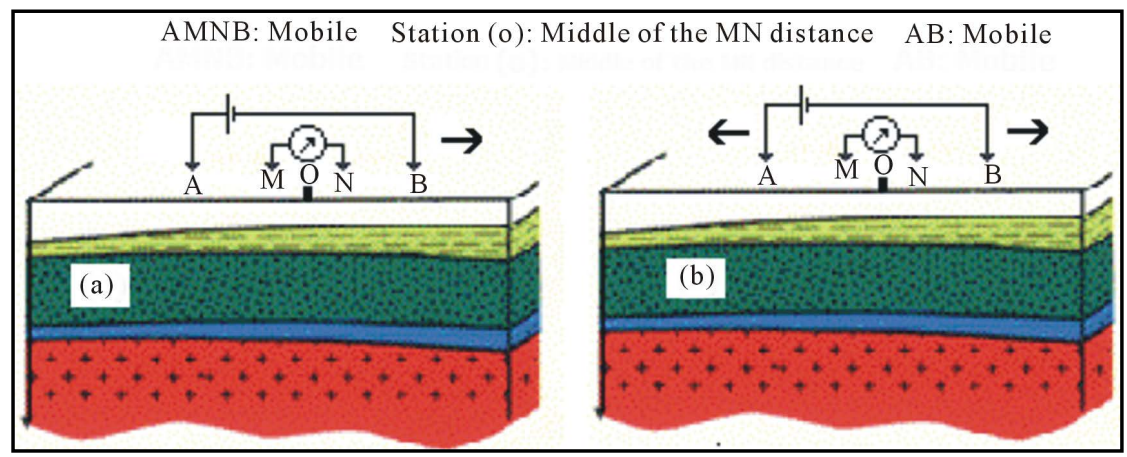

Figure 4. (a) Schlumberger electrical profiling, (b) Schlumberger electrical sounding. 
rite, $\cdots)$;

2) By electrical conductibility for which ions' displacement occurs in the fractures and pores fluid contents of rocks [14] [16].

The induced polarization causes electrochemical processes occurring when the current flows from an ionic conductibility medium (water) to an electronic conductibility medium or, from an ionic conductibility medium to a low conductive medium, or with a contact between two different ionic conductibility media [14] [16].

The results of the modelling of chargeability data can be presented as profiling curves, pseudo sections and maps depending on the dimensionality. The analysis of these results will enable to detect metal sulphides, clayey structures, graphite and some oxides in the area under study. It will therefore permit to assess the mineral potential of the target area without precision upon the nature of the mineralization.

\section{Material and Data Acquisition}

For a suitable coverage of the study area, a total of 64 geoelectrical soundings were processed along six (06) profiles of $1500 \mathrm{~m}$ each. The stations were designed following a variable grid $(100 \mathrm{~m} \times 200 \mathrm{~m}$ and $100 \mathrm{~m} \times 300$ $\mathrm{m})$ based on the triangular principle. The design of grids depends on the geographical coordinates recorded in the UTM33 WGS84 system.

To avoid the anisotropy effects of background geological formations [13], the profiles are SE-NW oriented. This direction is assumed to be transverse to that of underlying and suspected structures (Figure 5). The data are collected by combining the Schlumberger electrical sounding (VES) and electrical profiling (Figure 4).

The maximum length of electric wire AB used was $800 \mathrm{~m}$ in order to assess structures around $155 \mathrm{~m}$ depth [20] [25].

The campaign is hold in the Kellé-Bidjocka village and neighbourhoods, using DC resistivimeter Syscal Junior 48 (IRIS Instrument) following the Schlumberger array. This resistivimeter runs under Rho \& IP mode that enables to measure both the apparent resistivity (Rho) and the chargeability $(\boldsymbol{M})$ of the near subsurface structures [20].

The chargeability measurements are sensitive to ground induced electromagnetic field and resistance [21] [26]. Therefore, the acquisition of geoelectrical data is made by combining the direct and the reverse Schlumberger methods. The first technique consists in the injection of electrical current through current electrodes A and B, while the second uses the receiving electrodes $\mathrm{M}$ and $\mathrm{N}$ for the same purpose [20]. The uniqueness of this joint technique is guaranteed by the superimposition law, for the same cable's length.

The processing and modelling of geoelectrical data was realised with the Geotomo Res2dinv [27]-[29] which provides inverse pseudo sections of resistivity and chargeability that reflect the true resistivies and chargeabilities of buried structures of the study area [27] [28].

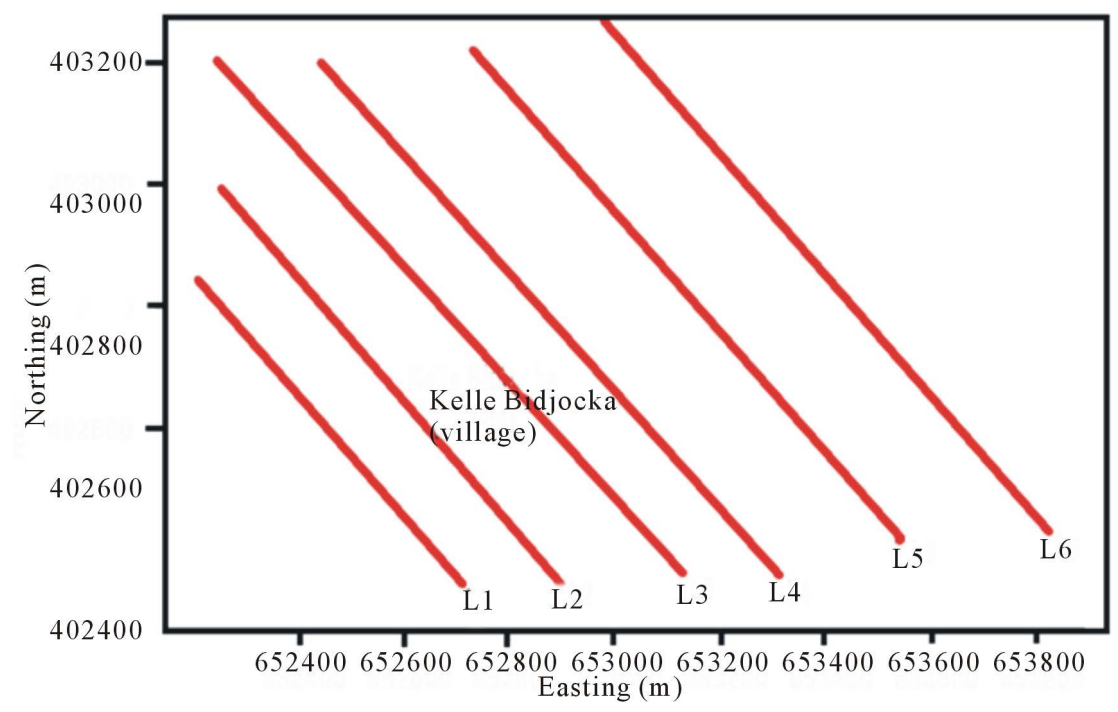

Figure 5. Profiles set in the study area. 
The sounding curves are plotted using Qwseln software version 2.23 [30] that enables to observe the variation of the resistivity with depth for each station.

The resistivity and chargeability maps show the spatial variation over the study area, by interpolating the related parameter. The maps are plotted with Surfer V.9.8.669 [31].

\section{Results}

\subsection{Analyses}

\subsubsection{Pseudo-Sections}

Plots presented in Figures 6-8 are inverse pseudo sections of apparent resistivity. They were realised with the Res2Dinv software and correspond respectively, to profiles L1 to L6. The depth of investigation reached was about $155 \mathrm{~m}$ on each profile. This depth corresponds to the maximum cable length ( $\mathrm{AB}=800 \mathrm{~m}$ ) according to the XL position along a profile.

The observation of profile L1 Figure 6(1) highlights, in its western part and up to $20 \mathrm{~m}$ depth, mean resistive bodies (Rho $\leq 1600 \Omega \cdot \mathrm{m})$.

Along this profile (89.5 $\mathrm{m} \leq \mathrm{XL} \leq 190 \mathrm{~m}$ ), an uplift of deep resistive structures (Rho $\geq 15,000 \Omega \cdot \mathrm{m}$ ) is noticeable up to $30 \mathrm{~m}$ depth. This upraise seems to end at $106 \mathrm{~m}$ near the $\mathrm{XL}=600 \mathrm{~m}$ position, in the north of the profile.

For $190 \mathrm{~m} \leq \mathrm{XL} \leq 600 \mathrm{~m}$, there is an uplift of resistive structures (Rho $<8000 \Omega \cdot \mathrm{m}$ ) looking like a pipe with a large aperture up to $25 \mathrm{~m}$ depth. The subvertical shape of iso resistivity contours intercalated between highly resistive structures suggest a major discontinuity or a fault, or shear zone.

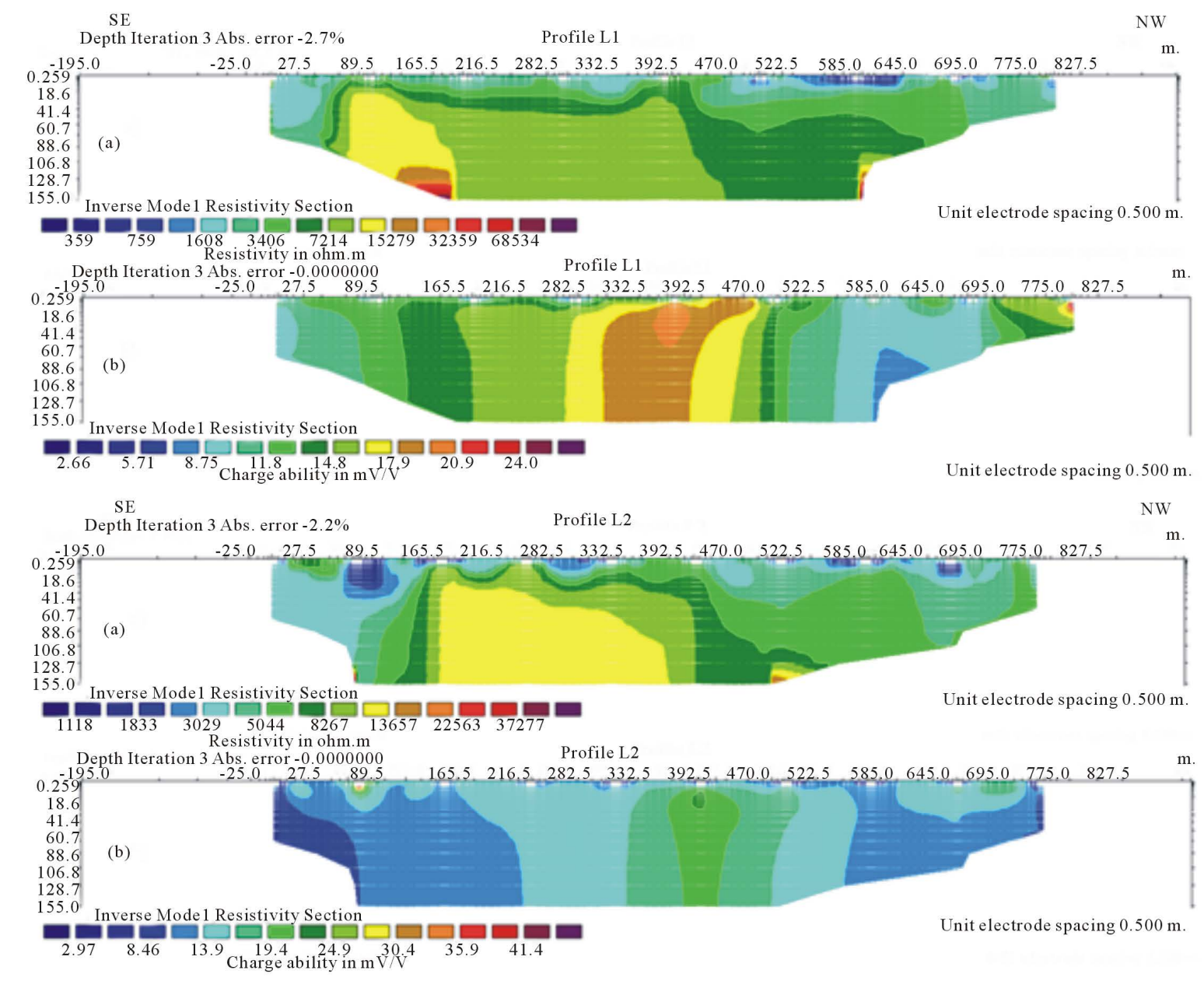

Figure 6. Pseudo-sections of apparent resistivity and chargeability of profiles L1 \& L2. 


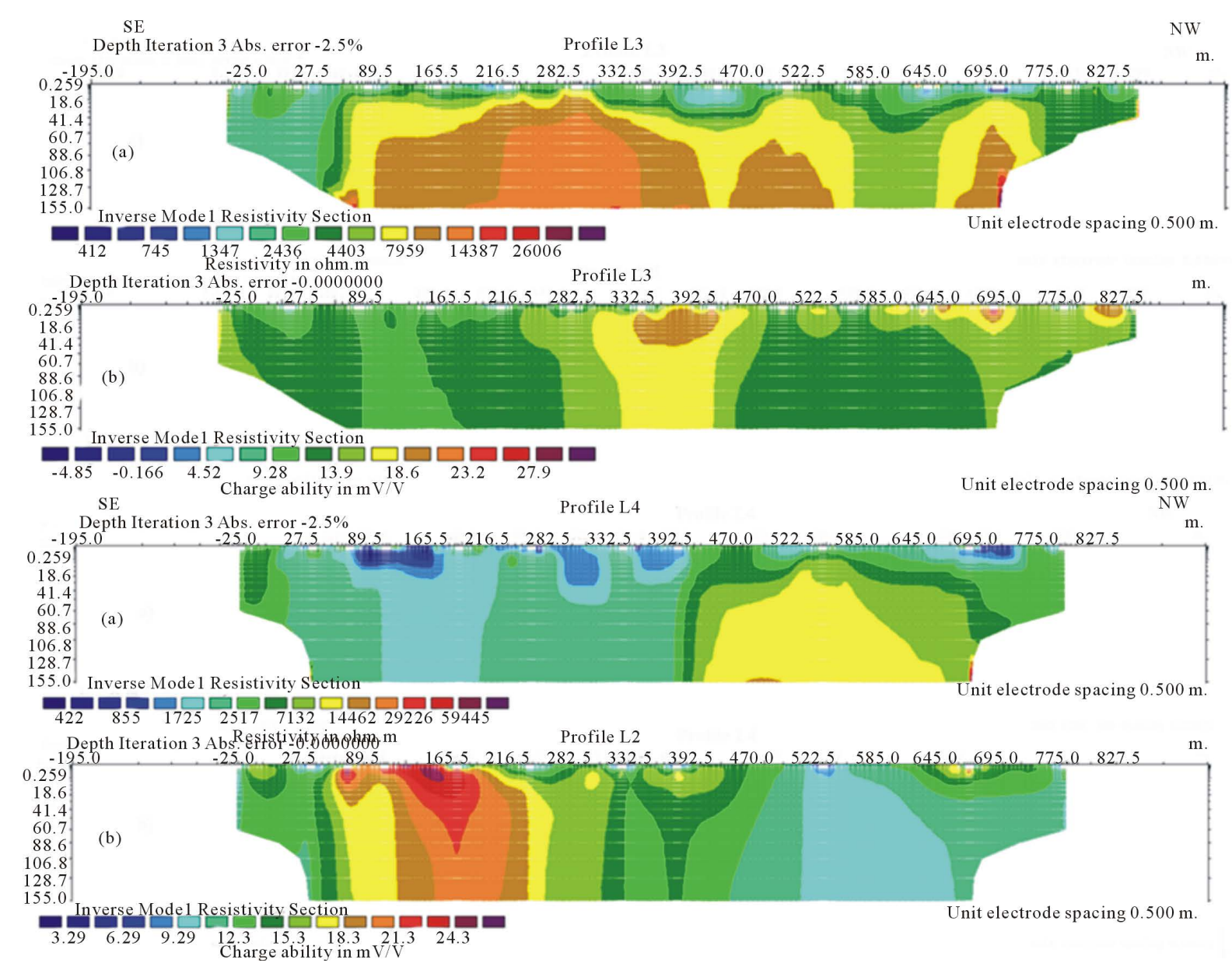

Figure 7. Pseudo-sections of apparent resistivity and chargeability of profiles L3 \& L4.

The width of this highly resistive structure seems to be extended to profile L2 Figure 6(2) for $215 \mathrm{~m} \leq \mathrm{XL} \leq$ $467 \mathrm{~m}$. It may be related to non feldspathic and fresh gneisses in the area. This extension implies the narrowing of the above mentioned mean resistive structure (Rho $<8000 \Omega \cdot \mathrm{m}$ ) for $467.5 \mathrm{~m} \leq \mathrm{XL} \leq 583.5 \mathrm{~m}$, thus forming an elongated mineralization channel.

Along profile L3 Figure 7(1) low resistive structure (Rho $<3000 \Omega \cdot \mathrm{m}$ ) are observed almost on the whole profile on near subsurface. Downward the resistivity increases with depth and highlights the bedding of resistive structures. This bedding is the witness of the intense tectonics that may have ruled on the area. Specifically in the north of the profile ( $850 \mathrm{~m} \leq \mathrm{XL} \leq 1000 \mathrm{~m}$ ), the above mentioned channel of low resistive structures (Rho < $3000 \Omega \cdot \mathrm{m}$ seems to reach profile L4 Figure $7(2)$, precisely in the south (235.5 $\mathrm{m} \leq \mathrm{XL} \leq 494 \mathrm{~m})$. This is characterized along profile L4 by a low resistivity value (Rho $<1800 \Omega \cdot \mathrm{m}$ ) enclosed right to left by high resistive structures (3500 < Rho $<15000 \Omega \cdot \mathrm{m}$ ). It may correspond to an infilling area of weathered structures or a weakness zone.

Along profile L5 Figure 8(1), two main low resistive (Rho $<2000 \Omega \cdot \mathrm{m}$ ) areas having a stretched triangular shape are observed (99 $\mathrm{m} \leq \mathrm{XL} \leq 470 \mathrm{~m}$ and $710 \mathrm{~m} \leq \mathrm{XL} \leq 900 \mathrm{~m}$ ) up to $155 \mathrm{~m}$ depth. Very conductive cores are enclosed within them (Rho $<600 \Omega \cdot \mathrm{m}$ ) at a depth less than $40 \mathrm{~m}$. These cores may correspond to feldspargneisses in this area close to swamps.

These are both unconformable within mean resistive $(2500 \Omega \cdot \mathrm{m}<$ Rho $<5000 \Omega \cdot \mathrm{m}$ ) to highly resistive (Rho $\geq$ $5000 \Omega \cdot \mathrm{m})$ structures. They are imprints of the continuation of the aforesaid channel or infilling zones.

The inaccessibility of the southern part of profile L6 Figure 8(2) was naturally inaccessible thus no data were collected there. Meanwhile, in its northern part (670 $\mathrm{m} \leq \mathrm{XL} \leq 746 \mathrm{~m}$ and $787.5 \mathrm{~m} \leq \mathrm{XL} \leq 836.5 \mathrm{~m})$, very conductive structures (Rho $<500 \Omega \cdot \mathrm{m}$ ) are observed at depths less than $30 \mathrm{~m}$ and $50 \mathrm{~m}$. These may correspond 


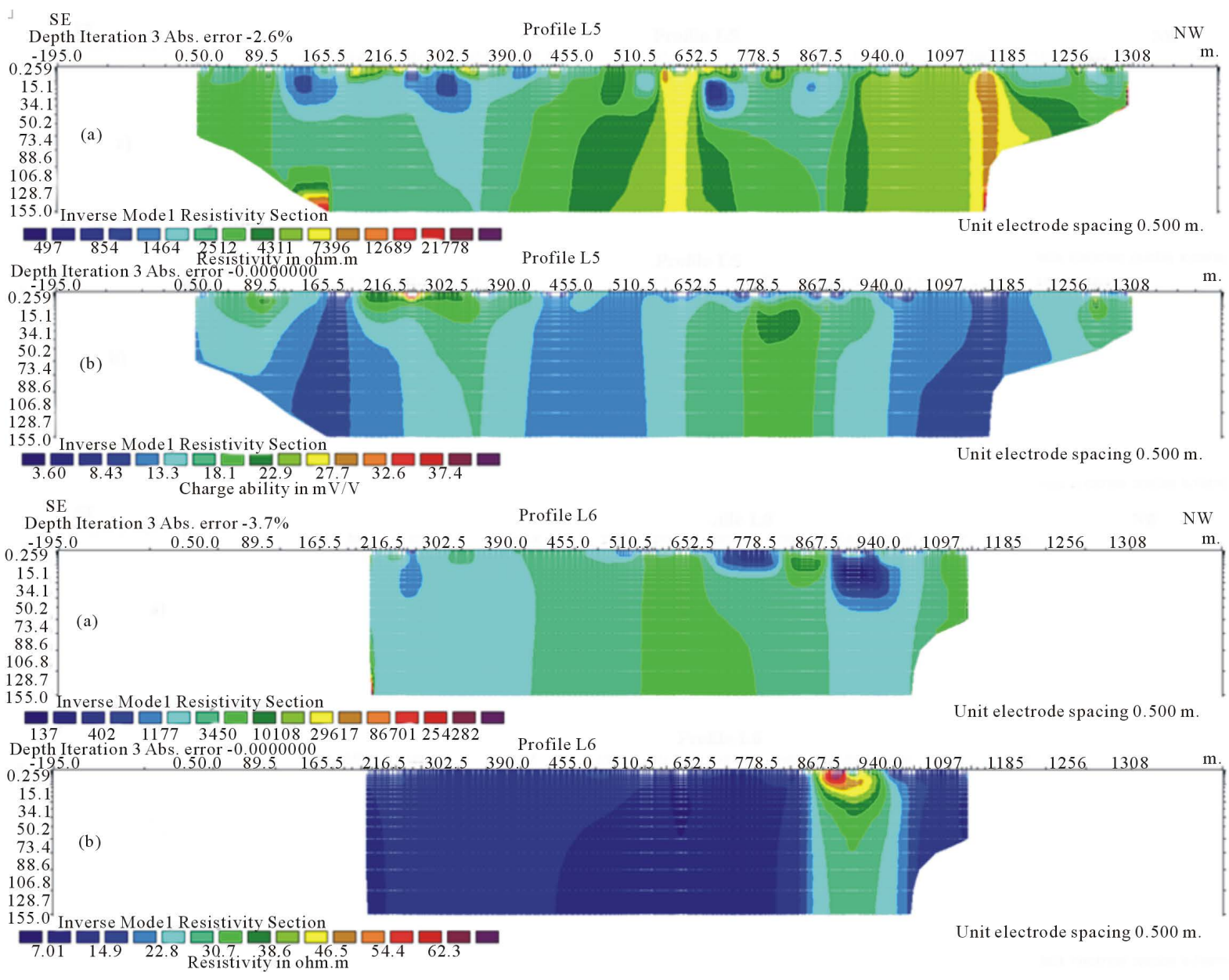

Figure 8. Pseudo-sections of apparent resistivity and chargeability of profiles L5 \& L6.

to aquifers or outcropping amphibolites in the area, or an iron mineralization.

The area (787.5 $\mathrm{m} \leq \mathrm{XL} \leq 885 \mathrm{~m}$ ) seems to be the northward continuation of the mineralization channel identified above [13] [15] [17] [20].

\subsubsection{Resistivity Maps}

Electrical profiling data $(\mathrm{AB}=32 \mathrm{~m}, \mathrm{AB}=110 \mathrm{~m}, \mathrm{AB}=210 \mathrm{~m}, \mathrm{AB}=390 \mathrm{~m}$ and $\mathrm{AB}=554 \mathrm{~m})$ enabled to plot resistivity maps using Golden Surfer. They show iso resistivity maps at depths corresponding respectively to 06 m, $21 \mathrm{~m}, 40 \mathrm{~m}, 74 \mathrm{~m}$ and $105 \mathrm{~m}$ (Figure 9). These maps enable to highlight and differentiate between conductive anomalies related to tectonic accidents (faults, fractures, shear zones, etc.), and resistive anomalies [13] [15]-[17].

Resistivity maps show that the study area is made up, from West to East, of very resistive, then conductive formations. Particularly in near subsurface surface $(6 \mathrm{~m}$ and $21 \mathrm{~m})$, conductive formations are mainly located in the west of the study area. An on surface widely extended mean resistive anomaly (around $3000 \Omega \cdot \mathrm{m}$ ) is characterized by NE stretched iso-contours. It narrows downward.

Otherwise, an up rise of underlying highly resistive (about $7000 \Omega \cdot \mathrm{m}$ ) materials occurs in the west of the study area at $105 \mathrm{~m}$ depth. These formations appear upward till $40 \mathrm{~m}$ depth (Figure 9) where they form an anomaly stretched along the NE axis. The curves' narrowing around the point whose coordinates are N 402,600 $\mathrm{m}-\mathrm{E} 652,500 \mathrm{~m}$, and between longitudes E 652,500 $\mathrm{m}$ and E 653,000 $\mathrm{m}$ (occurring at many points on maps from $21 \mathrm{~m}$ to $105 \mathrm{~m}$ depth), highlight discontinuities that may be interpreted as SW-NE faults. These faults bound at $40 \mathrm{~m}$ the dome constituted by above mentioned formations.

In general, resistivity maps show from West to East, a transition from resistive to conductive formations that 


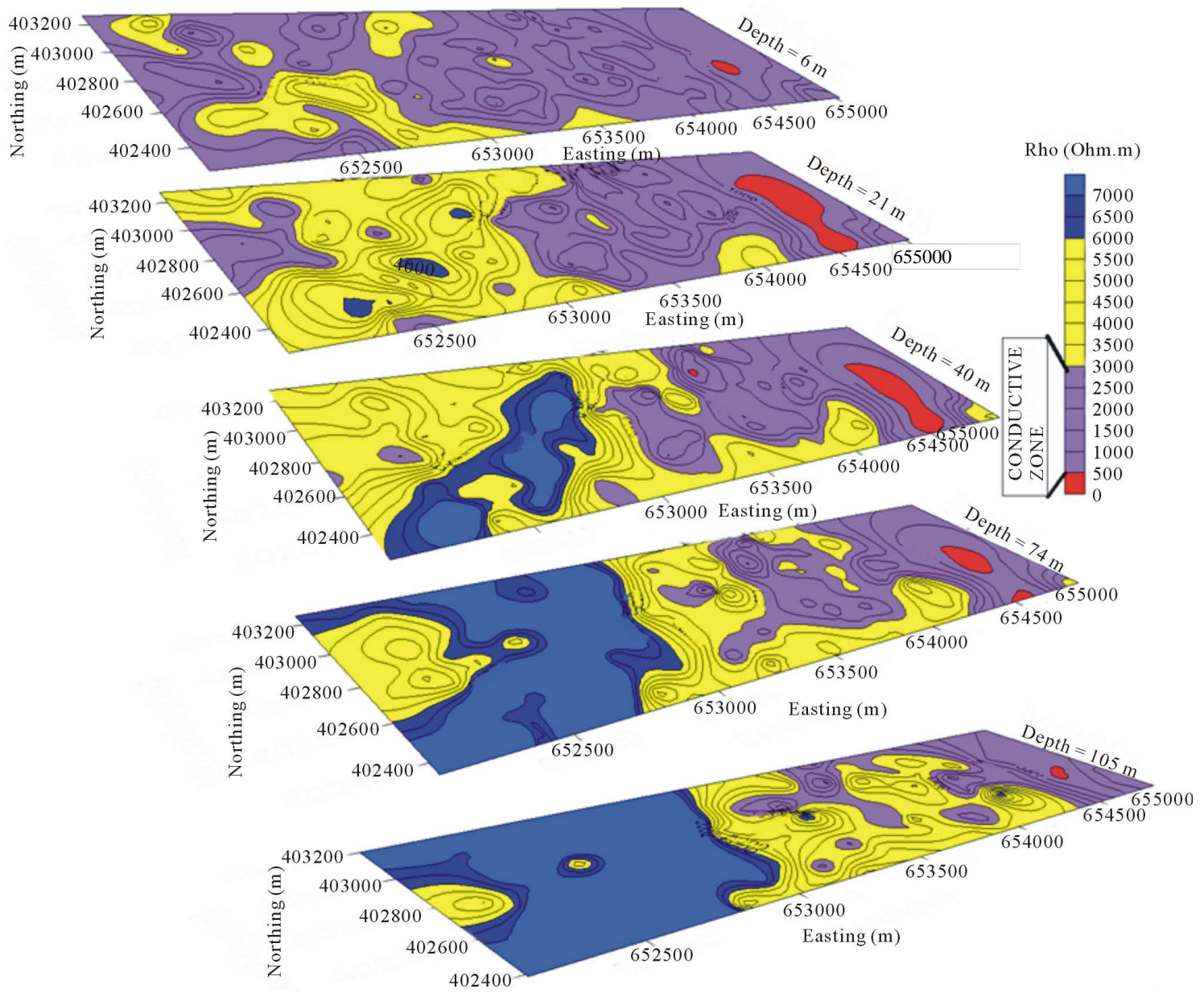

Figure 9. Resistivity maps of $(\mathrm{AB}=32 \mathrm{~m}, \mathrm{AB}=110 \mathrm{~m}, \mathrm{AB}=210 \mathrm{~m} \mathrm{AB}=390 \mathrm{~m}, \mathrm{AB}=554 \mathrm{~m})$.

follow the aforesaid stretched channel.

\subsubsection{Geological Section}

The Figures 10 and 11 present geoelectrical sections that show resistivity variations along profile L5 and L6. These sections were realised from sounding curves and geological data collected on field. These enable to sketch a qualitative geological cross section of the study area, and to estimate the thickness of potential iron formations [2].

The electrical soundings along profiles L5 and L6 were performed with a variable spacing (inter-station distance varying from $25 \mathrm{~m}$ to $250 \mathrm{~m}$ ) depending on the profiles.

Profile L5 exhibits at its South-East and at North-West (Figure 10), a three earth layered model. The overburden $(<10 \mathrm{~m})$ lies above a potentially low grade iron formation with a thickness varying from $45 \mathrm{~m}$ South-East to $90 \mathrm{~m}$ North-West. This conductive layer lies over the highly resistive gneissic bedrock. At the middle of the plot, a potentially high grade iron formation is evidenced; it has an average thickness of $80 \mathrm{~m}$.

The profile L6 geological cross section (Figure 11) is similar to that of profile L5, regarding the number of layers. However, in its south-eastern part, the overburden is thick $(25 \mathrm{~m})$ than in the north-western part (at least $10 \mathrm{~m}$ ). At the middle of the plot, potentially high grade iron formations drive themselves in the gneissic bedrock, with an average thickness greater than $150 \mathrm{~m}$.

Above all, the discontinuities (faults or fractures) observed through geological cross section enable to highlight tectonic accidents suggested by previous results. These witness the intense tectonics that rule over the area. In hydrogeological and mineral exploration, conductive or weathered layers in faulted or fractured area characterize the targets [15] [17] [32]. They match with mineralogical deposits or groundwater flows [2] [32] [33]. 

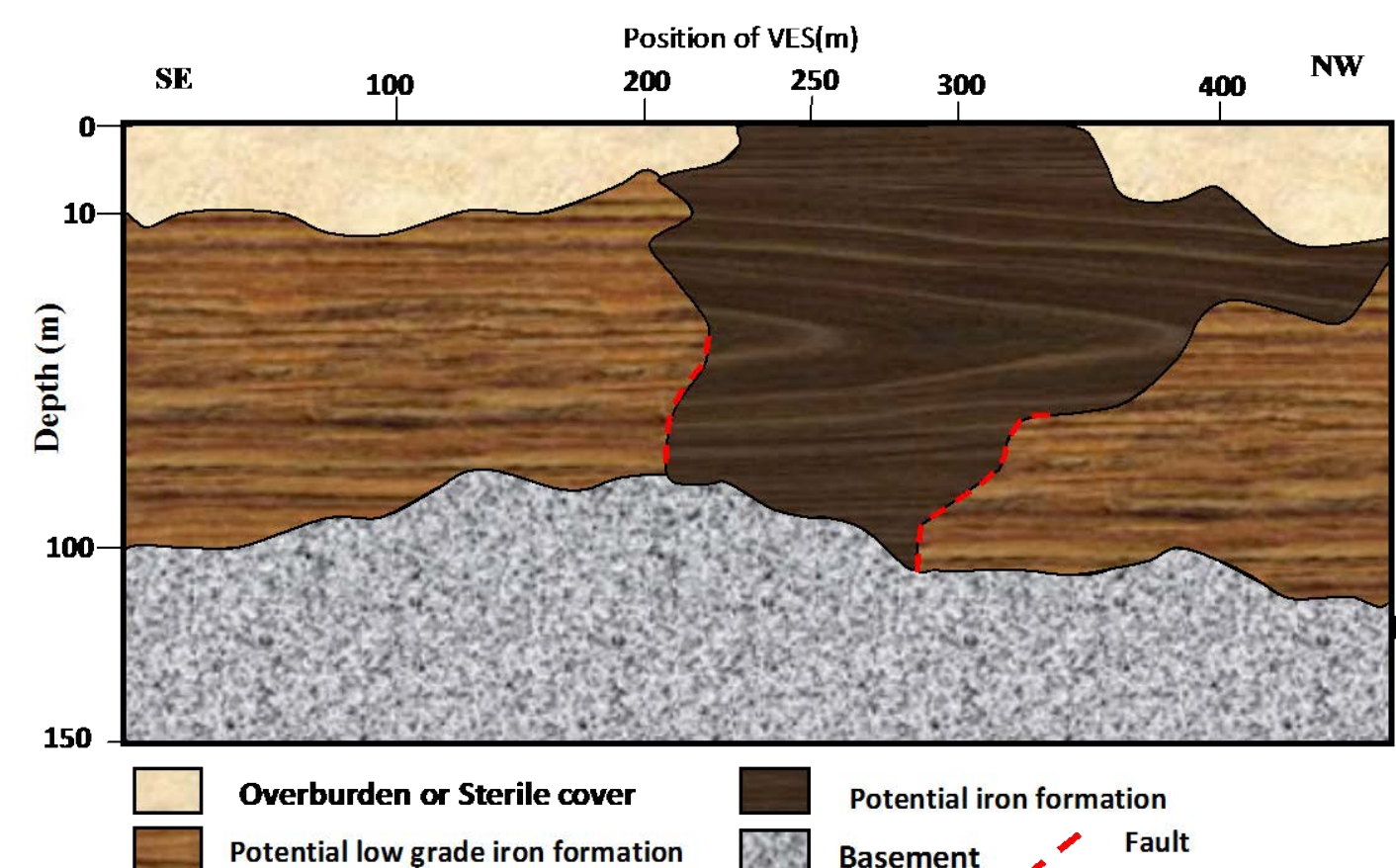

Figure 10. Geological section along of the profile L5.

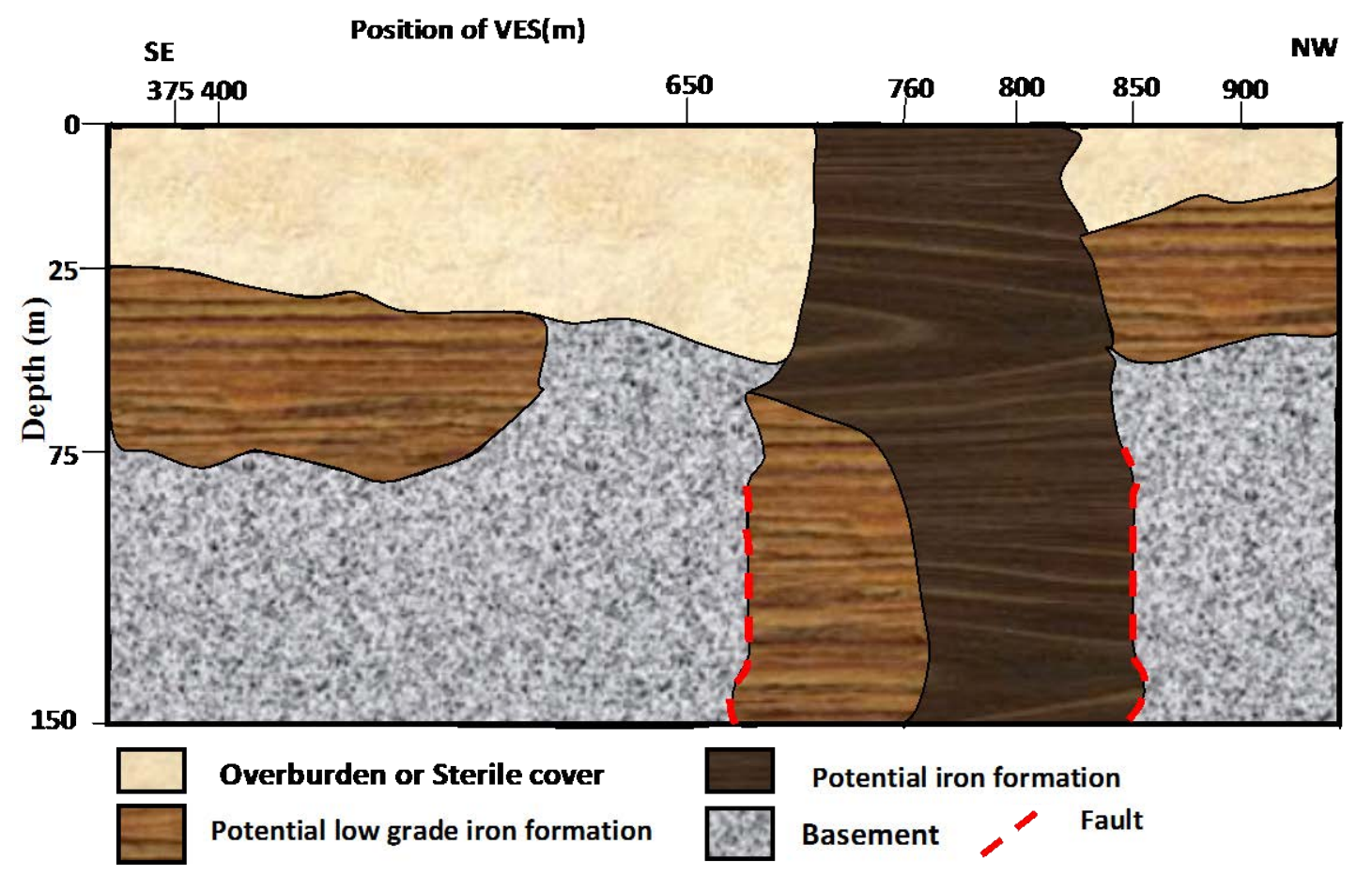

Figure 11. Geological section along of the profile L6.

\subsection{Induced Polarization (IP)}

\subsubsection{Pseudo-Sections}

Chargeability pseudo-sections shown (Figures 6-8) also correspond to profiles L1 to L6. They were realised with Geotomo Res2Dinv software. The depth of investigation reached for each profile is about $155 \mathrm{~m}$.

The observation of profile L1 Figure 6(1(b)) shows an anomaly of chargeability ( $M \geq 16 \mathrm{mV} / \mathrm{V}$ ) between 
$282.5 \mathrm{~m} \leq \mathrm{XL} \leq 490 \mathrm{~m}$. This anomaly is deep sited (depth $\geq 155 \mathrm{~m}$ ) and located within low chargeability structures $(\mathrm{M} \leq 14 \mathrm{mV} / \mathrm{V})$. This chargeability contrast enables to identify fault zone or an accumulation zone filled in by polarizable and conductive materials. The aforesaid anomaly is marked by a northward increase of chargeability and crosses profiles L2, L3, L4, L5 et L6 (Figures 6(2(b)), 7(1(b)), 7(2(b)), 8(1(b)) and 8(2(b))) respectively at $420 \mathrm{~m} \leq \mathrm{XL} \leq 635.5 \mathrm{~m} ; 500 \mathrm{~m} \leq \mathrm{XL} \leq 775 \mathrm{~m} ; 235.5 \mathrm{~m} \leq \mathrm{XL} \leq 550 \mathrm{~m} ; 216.5 \mathrm{~m} \leq \mathrm{XL} \leq 455 \mathrm{~m} ; 746.5 \mathrm{~m}$ $\leq \mathrm{XL} \leq 836.5 \mathrm{~m}$.

This anomaly seems to follow an oval channel as shown by Figure 13. This channel whose chargeability values are greater than $16 \mathrm{mV} / \mathrm{V}$ may be made up of high grade iron oxides mineralisation. The analysis of chargeability pseudo sections shows that the subsurface is jagged by faults.

The high chargeability anomalies recorded characterize the polarization of ground structures in situ [34]. They may be interpreted as high grade disseminated clayey sulphides or clayey ferriferous minerals [32] [34]-[36].

\subsubsection{Chargeability Map}

Figure 12 shows the distribution of chargeability at different depths (respectively, $06 \mathrm{~m}, 21 \mathrm{~m}, 40 \mathrm{~m}, 74 \mathrm{~m}$ and $105 \mathrm{~m}$ ) ploted with Surfer software. This distribution characterizes the horizontal variation of dissiminated polarisable structures for every depth level [14] [32].

This plot shows at near subsurface $(6 \mathrm{~m})$ in the West, the Centre and East of the study area, a chargeability anomaly $(16 \mathrm{mV} / \mathrm{V}<\boldsymbol{M}<22 \mathrm{mV} / \mathrm{V})$. The one located to the East is not perceptible in depth; hence we suggest it correlates weathered feldspathitic gneisses that outcrop around. The anomaly located at the centre of the study area is bounded left and right by less chargeability structures $(\boldsymbol{M}<15 \mathrm{mV} / \mathrm{V})$. This makes us suggest that it may correspond to a discontinuity interpreted as a fault or an accumulation zone [15]. The chargeability anomaly (16

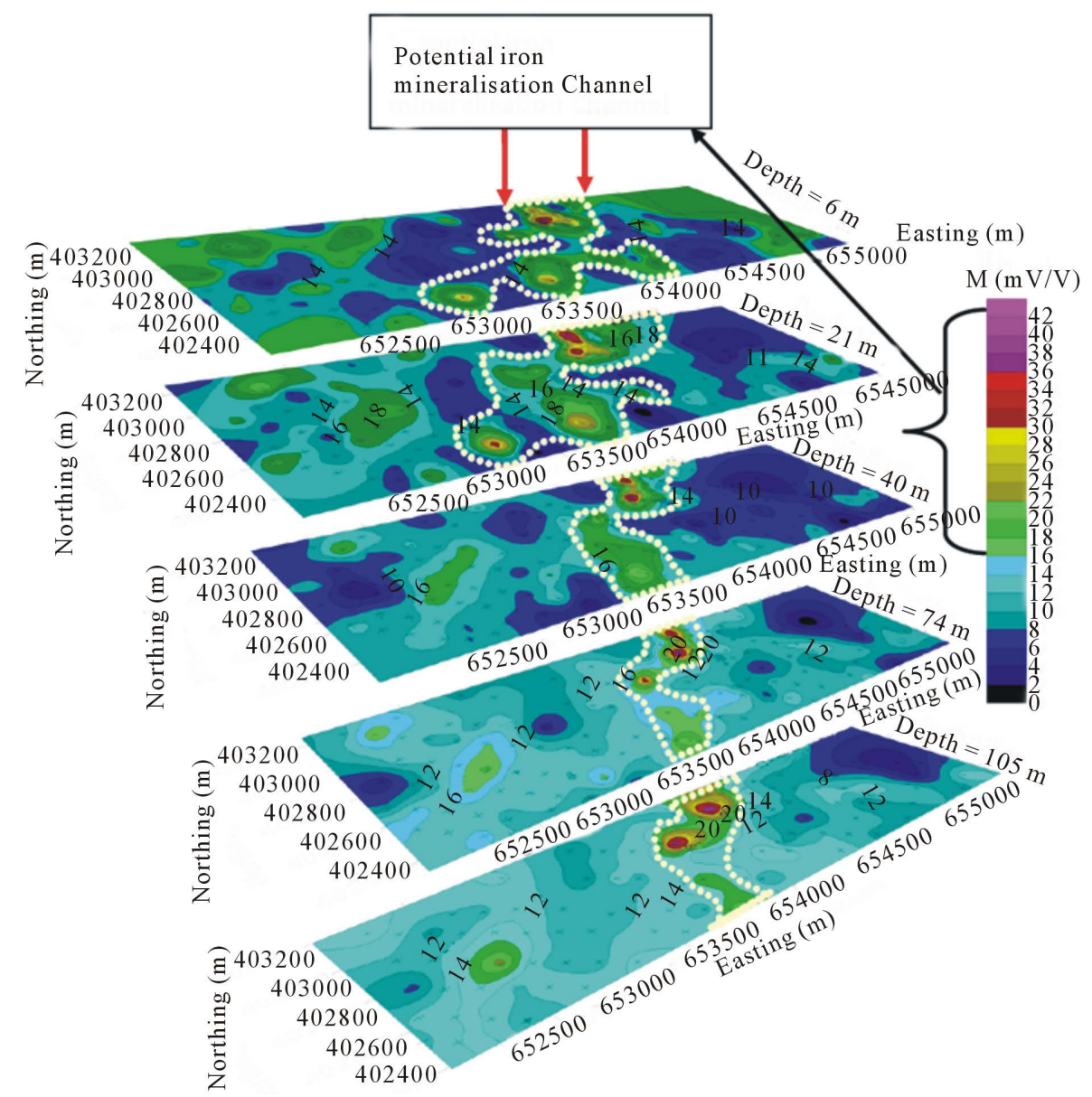

Figure 12. Chargeability maps of $(\mathrm{AB}=32 \mathrm{~m}, \mathrm{AB}=110 \mathrm{~m}, \mathrm{AB}=210 \mathrm{~m} \mathrm{AB}=390 \mathrm{~m}, \mathrm{AB}=$ $554 \mathrm{~m})$. 
$\mathrm{mV} / \mathrm{V}<\boldsymbol{M}<22 \mathrm{mV} / \mathrm{V}$ ) at the centre is very wide extended on surface (at $6 \mathrm{~m}$ depth). It is strong at depth, in the centre of the area between longitudes E 652,500 $\mathrm{m}$ and E 653,000 m, where it streches along a SW-NE axis (white dot lines in maps on Figure 12). The above chargeability anomaly remains perceptible at depth (at $105 \mathrm{~m}$ ) where it is centered at the point whose coordinates are N 402,600 m and E 652,500 m. It is shaped like a funnel downward and a faint secondary channel less extended than it. It keeps its NE strike. The SW-NE oval anomaly in the centre of the study area is marked by a relatively NW-SE to N-S shear. Chargeability values range (>16 $\mathrm{mV} / \mathrm{V}$ ) suggests that this anomaly corresponds to highly mineralized materials. Chargeability heights at different depths constitute the potential high grade iron ore mineralization [17] [37] [38].

\section{Discussion}

The quantitative and qualitative analyses of resistivity and chargeability contrasts on every profile provide good understandings of the ground electrical conductivity and polarization of the study area. Through those analyses, resistivity pseudo sections show that Kelle-Bidjocka underwent intense tectonics marked by upraises of underlying structures. These deformations go along with the set up of mineralization channels highlighted by chargeability pseudo sections (Figures 6-8).

The resistivity pseudo sections suggest several channels of conductive layers inside deep and low dip formations. These channels may be tectonic accidents (faults, fractures, shear zones, etc.), filling in places or flows of mineralogical fluids [13] [32]. The above discontinuities are also interpreted on resistivity maps (Figure 9) as faults or shear zones with a SW-NE trend.

The resistivity range (between 510 and $3000 \Omega \cdot \mathrm{m}$ ) recorded suggests that these shear zones are filled in by mineralization of interest.

The areas with a strong chargeability response are targetable because they may be of high grade mineralization [14] [32] [35]. Therefore, the chargeability range ( $\mathrm{M}>16 \mathrm{mV} / \mathrm{V})$ suggests that the identified anomaly on maps may correspond to high grade iron formations. The resistivity range (between 510 and $3000 \Omega \cdot \mathrm{m}$ ) of these structures, combined with in situ geological facts allow correlating them to iron formations.

However, some highly polarizable and conductive outcomes may mislead to interesting targets while these rather be located in swamp surroundings. These last are due to weathered feldspathitic gneisses or amphibolites which outcrop around.

We also suggest that highly conductive areas with low IP response, may correspond to sulphides mineralizations that characterise ground water [33] [35] [39].

Through the analyses made on Chargeability pseudo-sections (Figures 6(1(b), 6(2(b)), 7(1(b)), 7(2(b)), 8(1(b)) and 8(2(b))), a probable mineralization channel (Figure 12) corresponding to high chargeability values have been delineated. Chargeability highs at different depths in some areas show that these areas may constitute probable high grade mineralization targets.

The geological reconnaissance of outcrops and the interpretation of sounding curves along profiles L5 and L6 enabled to plot geological cross sections. These plots are rough imaging of the area's subsurface.

The outcrops and resistivity and chargeability value ranges recorded, permitted to suggest various formations and tectonic accidents observed along profiles L5 and L6 (Figures 10 and 11).

The strike of the mineralization is SW-NE; this is the witness of the importance of tectonics in the area. This tectonics is controlled by NE-SW transcurrent movements of the Centre Cameroon Shear Zone characterized in the area by the Eséka-Dja fault [3] [7] [9] [40].

The location of the study area, at the North-West margin of the Congo Craton in a paleo platform context suggests that, probable formations containing iron mineralization, and thus evidenced may be of "high grade" type or BIFs. These formations may correlate with available geologic data, and those collected in situ.

\section{Conclusions}

The field geological investigation reveals that the main formations are gneisses and amphibolites. In the middle of the area under investigation, there are gneisses intercalated into iron occurrences, while gneisses in the West are more crystalline and richer in feldspar. Granitic formations outcrop also at the middle of the area, and seem to undergo fracturing and folding processes. The BIFs present light beds that may correspond to quartz intercalation.

The Schlumberger geoelectrical profiling and sounding investigation was carried out in Kellé-Bidjocka vil- 
lage, Messondo subdivision (Centre Region, Cameroun), using the direct current resistivimeter Syscal Junior 48 (IRIS Instrument). The geoelectrical data have permitted to highlight weakness zones or conductive discontinuities (faults, fractures, shear zones, etc.) in Precambrian gneisses, sometimes weathered. These are identified as weathering or mineralogical accumulation horizons, the most probing is the SW-NE trending mineralization channel revealed by the study. This mineralization is characterized by strong chargeability or polarization gradients.

The field Samples and other geological evidences recorded in the area enable to link the most polarizable structures to iron formations. Weakly polarizable and particularly conductive backgrounds identified by the inverse pseudo-sections are thought to be sulphate minerals or groundwater targets for future hydrogeological studies. The discontinuities and formation evidenced through geological cross sections from profiles L5 and L6 are witnesses of geological events and tectonics that occurred in the area.

\section{Acknowledgements}

The authors are grateful to BOCOM Petroleum SA \& CIDER Services-BGG-EXMIP for giving them the opportunity to participate to the collection, providing geoelectrical data set and processing software used in this study. Their thanks are also addressed to the reviewers, for their kind remarks making the manuscript clearer and more pertinent.

\section{References}

[1] Cornachia, M. and Dars, R. (1983) Un trait majeur du continent africain. Les Linéaments centrafricains du Cameroun au Golfe d'Aden. Bulletin de la Societe Geologique de France, 7, 102-109.

[2] Gouet, D.H., Ndougsa-Mbarga, T., Meying, A., Assembe, S.P. and Man-Mvele Pepogo, A.D. (2013) Gold Mineralization Channels Identification in the Tindikala-Boutou Area (Eastern-Cameroon) Using Geoelectrical (DC\& IP) Methods: A Case Study. International Journal of Geosciences, 4, 643-655. http://dx.doi.org/10.4236/ijg.2013.43059

[3] Meying, A., Ndougsa Mbarga, T. and Manguelle-Dicoum, E. (2009) Evidence of Fractures from the Image of the Subsurface in the Akojolinga-Ayos Area (Cameroon) by Combining the Classical and the Bostick Approaches in the Interpretation of Audio-Magnetotelluric Data. Journal of Geology and Mining Research, 1, 159-171.

[4] Mvondo, H., Den-Brok, S.W.J. and Mvondo-Ondoa, J. (2003) Evidence for Symmetric Extension and Exhumation of the Yaoundé Nappe (Pan-African Fold Belt, Cameroon). Journal of African Earth Sciences, 35, 215-231. http://dx.doi.org/10.1016/S0899-5362(03)00017-4

[5] Mvondo, H., Owona, S., Mvondo-Ondoa, J. and Essono, J. (2007) Tectonic Evolution of the Yaoundé Segment of the Neoproterozoic Central African Orogenic Belt in Southern Cameroon. Canadian Journal of Earth Sciences, 44, 433444. http://dx.doi.org/10.1139/e06-107

[6] Olinga, J.B., Mpesse, J.E., Minyem, D., Ngako, V., Ndougsa-Mbarga, T. and Ekodeck, G.E. (2010) The Awaé-Ayos Strike-Slip Shear Zones (Southern-Cameroon): Geometry, Kinematics and Significance in the Late Panafrican Tectonics. Neues Jahrbuch für Geologie und Paläontologie, 257, 1-11.

[7] Mbom-Abane, S. (1997) Investigation Géophysique en Bordure du Craton du Congo (région d’Abong-Mbang/ Akonolinga, Cameroun) et Implications Structurales. Thèse Doctorat d’Etat ès Sciences, Université de Yaoundé I, Fac. Sciences.

[8] Ndougsa-Mbarga, T., Meying, A., Bisso, D., Layou, D.Y., Sharma, K.K. and Manguelle-Dicoum, E. (2011) Audiomagnetotellurics (AMT) Soundings Based on the Bostick Approach and Evidence of Tectonic Features along the Northern Edge of the Congo Craton, in the Messamena/Abong-Mbang Area (Cameroon). Indian Geophysical Union, 15, 145-159.

[9] Ndougsa-Mbarga, T., Manguelle-Dicoum, E., Tabod, C.T. and Mbom-Abane, S. (2003) Modelisation d'anomalies gravimétriques dans la region de Mengueme-Akonolinga (Cameroun). Science, Technology and Development, 10, 6774.

[10] Rolin, P. (1995) La Zone de Décrochement Panafricain des Oubanguides en République Centrafricaine. C.R. Academy Society, Paris.

[11] Seguin, M.K. (1971) La géophysique et les propriétés des roches. Les Presses de l’Université, Laval, 562 p.

[12] Seguin, M.K. (1974) The Use of Geophysical Methods in Permafrost Investigation: Iron Ore Deposits of the Central Part of the Labrador Trough, Northeastern Canada. Geoforum, 5, 55-67.

[13] Burger, R.H., Sheehan, F.A. and Jones, C.H. (2006) Introduction to Applied Geophysics: Exploring the Shallow Subsurface. Norton \& Company, Inc., New York, 265-347.

[14] Sumner, J.S. (1976) Principles of Induced Polarization for Geophysical Exploration. Elsevier, Amsterdam, 227 p. 
[15] Keary, P. and Brooks, M. (1991) An Introduction to Geophysical Exploration. 2nd Edition, Blackwell Scientific Publications, Oxford, $254 \mathrm{p}$.

[16] Parasnis, D.S. (1997) Principles of Applied Geophysics. 5th Edition, Chapman and Hall, London, 104-176.

[17] Tijani, M.N., Osinowo, O.O. and Ogedengbe, O. (2009) Mapping of Sub-Surface Fracture Systems Using Integrated Electrical Resistivity Profiling and VLF-EM Methods: A Case Study of Suspected Gold Mineralization. RMZ-Materials and Geoenvironment, 56, 415-436.

[18] Ward, S.H. (1990) Resistivity and Induced Polarization Methods. In: S. H. Ward, Ed., Geotechnical and Environmental Geophysics, 2nd Edition, Society of Exploration Geophysicists, Tulsa, 147-190.

[19] Bakkali, S. and Bouyalaoui, J. (2005) Essai d'optimisation de la capacité de retenue d'eau d'un lac par caractérisation géophysique du recouvrement argiìeux. African Journal of Science and Technology (AJST). Science and Encineering Series, 6, 12-22.

[20] Chapellier, D. (2000) Prospection électrique en surface. Cours de géophysique. Université de Lausanne, Institut Français de Pétrole, 98 p.

[21] Béhaegel, M. and Gourry, J.C. (2003) Investigation de pollutions organiques par méthodes géophysiques. Rapport BRGM/RP-52642-FR, 89.

[22] Fink, J.B., McAlester, E.O., Sternberg, B.K., Ward, S.H. and Wieduwilt, W.G. (1990) Induced Polarization, Applications and Case Studies. Society of Exploration Geophysicists, 414. http://dx.doi.org/10.1190/1.9781560802594

[23] Seguin, M.K. (1971) Applications des méthodes électriques aux problèmes de genie. L’Ingénieur, 12-21.

[24] Kiberu, J. (2002) Induced Polarization and Resistivity Measurements on a Suite of Near Surface Soil Samples and Their Empirical Relationships to Selected Measured Engineering Parameters. MSc Thesis, ITC, Enschede.

[25] Loke, M.H. (2000) Electrical Imaging Surveys for Environmental and Engineering Studies. A Practical Guide to 2-D and 3-D Surveys, 61.

[26] Loke, M.H. (2004) Tutorial: 2-D and 3-D Electrical Imaging Surveys. Geotomo Software, Res2dinv 3.5 Software.

[27] Loke M.H. (1994) The Inversion of Two Dimensional Resistivity Data. Ph.D. Thesis, University of Birmingham, Birmingham, 122.

[28] Loke, M.H. and Barker, R.D. (1996) Rapid Least-Squares Inversion of Apparent Resistivity Pseudosections by a Quasi-Newton Method. Geophysical Prospecting, 44, 131-152. http://dx.doi.org/10.1111/j.1365-2478.1996.tb00142.x

[29] Res2dinv ver. 3.59 for Windows XP/Vista/7 (2010) Rapid 2-D Resistivity \& IP Inversion Using the Least-Squares Method. Geoelectrical Imaging 2D \& 3D Geotomo Software, Malaysia.

[30] Tabbach, J. (2004) Qwseln. Version 2.23, programme d’interprétation des sondages électriques. C.N.R.S., UMR7619.

[31] Surfer, V.9.8.669, Surface Mapping System Copyright (c) 1993-1999. Golden Software, Inc., Colorado, 1866.

[32] Salmirinne, H. and Turunen, P. (2007) Ground Geophysical Characteristics of Gold Targets in the Central Lapland Greenstone Belt. Geological Survey of Finland, Special Paper, 44, 209-223.

[33] Dahlin, T., Rosquist, H. and Leroux, V. (2010) Resistivity_IP for Landfill Application. First Break, 28, 101-105.

[34] Meju, M.A. (2002) Geoelectromagnetic Exploration for Natural Resources: Models, Case Studies and Challenges. Surveys in Geophysics, 23, 133-205. http://dx.doi.org/10.1023/A:1015052419222

[35] Campbell, D.L. and Fitterman, D.V. (2000) Geoelectrical Methods for Investigating Mine Dumps. In: Proceedings of the 5th International Conference on Acid Rock Drainage (ICARD), Vol.2, Denver, 21-24 May 2000, Society for Mining, Metallurgy, and Exploration, Inc., Littleton, 1513-1523.

[36] Holliday, J.R. and Cooke, D.R. (2007) Advances in Geological Models and Exploration Methods for Copper \pm Gold Porphyry Deposits. Ore Deposits and Exploration Technology, 53, 791-809.

[37] Klein, C. (2005) Some Precambrian Banded Iron-Formations (BIFs) from around the World: Their Age, Geologic Setting, Mineralogy, Metamorphism, Geochemistry and Origin. American Mineralogist, 90, 1473-1499. http://dx.doi.org/10.2138/am.2005.1871

[38] Slack, J.F. and Cannon, W.F. (2009) Extraterrestrial Demise of Banded Iron Formations 1.85 Billion Years Ago. Science, 37, 1011-1014.

[39] Boiero, D., Godio, A., Naldi, M. and Yigit, E. (2010) Geophysical Investigation of a Mineral Groundwater Resource in Turkey. Hydrogeology Journal, 18, 1219-1233.

[40] Manguelle-Dicoum, E., Nouayou, A.S., Bokossah, A.S. and Kwende-Mbanwi, T.E. (1993) Audiomagnetotelluric Soundings on the Basement-Sedimentary Transition Zone around the Eastern Margin of the Douala Basin in Cameroun. Journal of African Earth Sciences, 17, 487-496. http://dx.doi.org/10.1016/0899-5362(93)90006-C 